This is a self-archived version of an original article. This version may differ from the original in pagination and typographic details.

Author(s): Lähdesmäki, Tuuli

Title: Temporary Architecture as a Means in Urban Regeneration

Year: 2018

Version: Accepted version (Final draft)

Copyright: (c) 2018 Koninklijke Brill NV.

Rights: In Copyright

Rights url: http://rightsstatements.org/page//nC/1.0/?language=en

Please cite the original version:

Lähdesmäki, T. (2018). Temporary Architecture as a Means in Urban Regeneration. In T.

Lähdesmäki (Ed.), Time and Transformation in Architecture (pp. 19-43). Brill. At the Interface / Probing the Boundaries, 100. https://doi.org/10.1163/9789004376793_003 


\title{
Temporary Architecture as a Means in Urban Regeneration
}

\author{
Tuuli Lähdesmäki
}

\section{Architecture and Time}

Architecture is both a product and a process that combines not only esthetics and functionality, but also a broad variety of cultural, social, societal, and political meanings. It binds together materiality and immaterial and intangible values. Since antiquity and the influential architectural theories of Vitruvius (c. 80-70 BC to c. 15 BC), the ideals of Western architecture have comprised an aim for durability, or firmitas in Vitruvius's terms. ${ }^{1}$ Indeed, the ideas of temporality and movability do not belong to the traditional notions of Western architecture. On the contrary, these notions often carry within them the idea of eternity: architecture is seen as something that is transmitted from one generation to another and with this continuity it transforms into the history of the community. As materialized history, architecture is often considered to comprise the values of the time of its construction and to be able to transmit them to the present. In the disciplines of art history, cultural history, and heritage studies, architecture is often approached and explored as cultural heritage - as artifacts that manifest and scrutinize the cultural ideas of the past generations. Due to this heritage function and value, preservation and conservation of architecture are considered important not only within the views of these disciplines, but also more broadly in Western societies. These traditional notions of Western architecture are manifested in the narration of Western architectural history. It is commonly told as a continuation of impressive creations of famous architects and a series of iconic landmarks and cultural heritage sites in major cities of the Western world.

In reality, architecture is never eternal, but rather transforming and temporal. The construction of the so-called masterpieces of Western architectural history has also often been processual. It may have taken centuries to build them and, thus, their architecture is a combination of various historical layers. The form, style, spatial structure, function, and use of these buildings may have changed several times during their history. Gothic churches are interesting examples of the processual dimensions and transforming characteristics in architecture. Many Gothic churches were built between the 13th and 16th centuries, but in some cases their construction was not finished until the 19th century. For example, construction of the Gothic Cologne Cathedral was started in 1248 and was finally completed in 1880. In Barcelona, the Art Nouveau church Sagrada Família by Antoni Gaudí was commenced in 1882 and is still under construction. The iconic cathedrals and churches in European cities are also good examples of the transforming functions of architecture. Buildings that used to serve mainly religions purposes have been transformed into touristic spaces, museumized and heritagized sites, and visual icons commonly utilized for marketing, place promotion, and city branding, and, thus, changing the meanings of architecture. ${ }^{2}$

All architectural creations have a certain life span, and in some cases the span may be planned to be relatively short. Many buildings are intentionally constructed with methods and materials that have limited durability. Buildings may have been planned as temporary due to a sudden and temporal need to house a large group of people, such as immigrants, refugees, or soldiers. In addition, several venues for mega-events, such as sport games, have been constructed to be used only during the events. For example, in the London Olympic Games in

\footnotetext{
${ }^{1}$ Vitruvius, The Ten Books on Architecture, trans. Morris Hicky Morgan (Cambridge: Harvard University Press, 1914).

${ }^{2}$ Dean MacCannell, The Tourist. A New Theory of the Leisure Class (New York: Schocken Books, 1989$), 43$.
} 
2012, several sports halls and arenas were constructed with materials and techniques that enabled downsizing, dismantling, and recycling of the buildings and/or moving and rebuilding them in another place.

Western architectural history includes a certain architectural genre-pavilions and venues of international exhibitions and world fairs - in which the architectural creations are intentionally planned to exist only temporarily while at the same time being profoundly outstanding. Many of these pavilions are today known only from photographs and drawings, but some of them have turned out to be much longer-lasting than was originally planned. In some cases these pavilions and exhibition venues, such as the Eiffel Tower (1889) in Paris or the Atomium in Brussels (1958), have become iconic landmarks and tourist attractions and acquired a heritage value, and they function as manifestations of ideas and world views of the time of their construction.

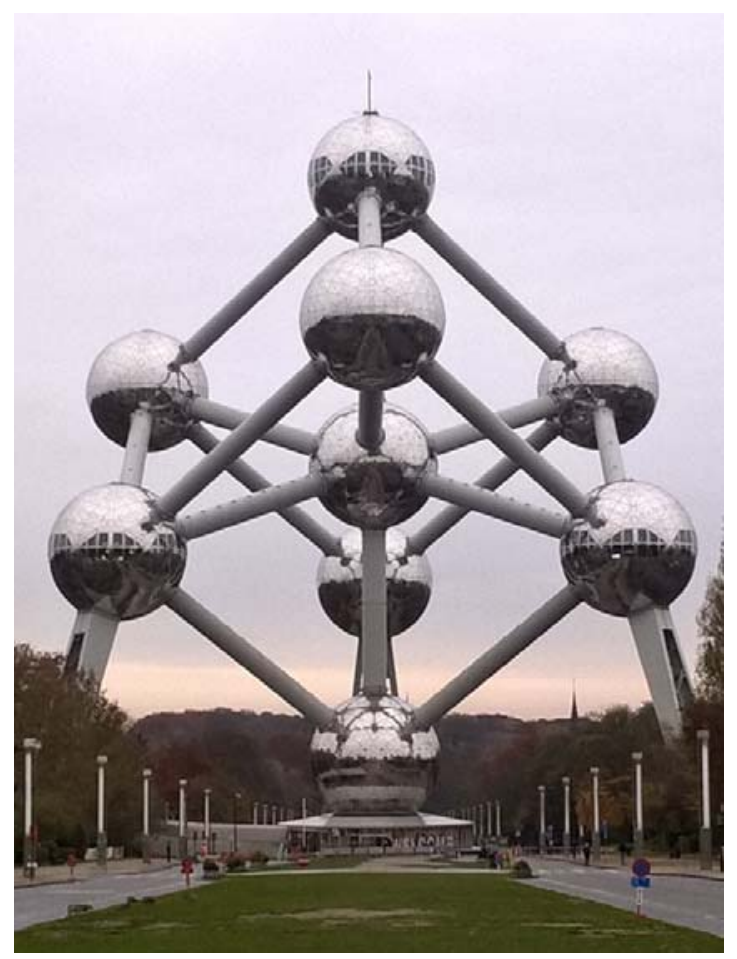

Figure 2.1. Atomium, designed by André Waterkeyn, André Polak, and Jean Polak, 1958, Brussels, Belgium. Photo: Tuuli Lähdesmäki.

The idea of temporality has been recently much discussed and explored in contemporary architecture. Recent practices of urban regeneration have utilized the possibility of creating temporary architectural spaces to enliven less-used or abandoned sites, to offer the local people venues for various communal activities, and to entice both the citizens and visitors in the cities to spend time in them. The idea of temporality opens a variety of new possibilities for thinking about and practicing architecture.

Since 2000, the European Union (EU) has become more and more interested in urban development as a tool for influencing European cities. One of the EU's longest running and perhaps most well-known and influential cultural initiatives - the annual designation of the European Capital of Culture (ECOC) - encourages European cities to promote local and economic development through diverse cultural activities and urban projects. The initiative was launched in 1985 and run as a European-level intergovernmental scheme under the name 
European City of Culture until 1999, when it was transformed into a Community action of the European Parliament and Council and renamed European Capital of Culture. Many of the designated cities have invested in large-scale infrastructure and construction projects before, during, and/or after their ECOC year. Moreover, the limited length of the ECOC designation (one year) has led the cities to implement and host various small-scale temporary architectural projects in which city spaces are altered through various tactics to achieve diverse cultural, social, political, and economic goals.

In this chapter, I examine the diversity of tactics and goals of temporary architectural projects in four ECOCs-Turku (Finland), Tallinn (Estonia), Maribor (Slovenia), and Marseilles (France) - and discuss how temporary architectural intervention into an urban space is intended to work as a means of urban regeneration. The research material of the study consists of diverse planning and promotional materials of the architectural project cases, their observation in situ, and discussions about the projects with various local people and cultural actors during my field research and visits to the cities. This rich and manifold research material is approached with data-driven inductive logic of inquiry that seeks to understand temporary architecture in the context of recent theoretical discussions and conceptualizations of cultural policy research, urban studies, and culture studies.

The chapter starts from a brief theoretical discussion on the role of architecture in urban regeneration followed by a discussion on the ECOC initiative and the selected temporary architectural projects and the tactics of temporality and the goals of regeneration included in them. The article ends with a discussion on these tactics and goals in the contexts of recent urban planning theories and general conclusions about the study.

\section{The Role of Architecture in Urban Regeneration}

The intertwined emphasis on economic and cultural development and the interconnections between the spheres of culture and economy characterize current discourses on cultural policy in the Western world. ${ }^{3}$ The spheres of culture and economy form an inter-discursive domain in which culture is commonly transformed into an economic keyword. ${ }^{4}$ The concepts of creative economy and cultural economy-which have often been referred to in cultural policy discourses and urban development and management talk during the past two decades - are based on the idea of a correlation between cultural and economic development: strengthening one of them is considered to advance the other, as well. In addition, the economic dimension of culture has often been intertwined with urbanity. Cities have been considered drivers of economic growth, with urban space as a factor supporting that function..$^{5}$ Thus, in cultural policy discourses and urban development and management talk, the ideas of urban space, culture, creativity, and economy form an interrelated and inter-determined sphere of meanings. ${ }^{6}$

During recent decades, decision-makers and urban planners have sought to advance the economic growth of Western cities by promoting diverse cultural projects and development of the city space. These aims have been discussed and conceptualized within academia with the

\footnotetext{
${ }^{3}$ Lluís Bonet and Emmanuel Négrier, "The Ends(s) of National Cultures? Cultural Policy in the Face of Diversity,” International Journal of Cultural Policy 17, no. 5 (2011): 574-589.

${ }^{4}$ See for example, Hans Erik Näss, "The Ambiguities of Intercultural Dialogue: Critical Perspectives on the European Union's New Agenda for Culture,” Journal of Intercultural Communication 23 (2010).

${ }^{5}$ Kaarin Taipale, Cities for Sale. How Economic Globalization Transforms the Local Public Sphere (Espoo: Helsinki University of Technology, 2009), 42.

${ }^{6}$ Tuuli Lähdesmäki, "European Capital of Culture Designation as an Initiator of Urban Transformation in the Post-Socialist Countries," European Planning Studies 22, no. 3 (2014): 481-497.
} 
concepts of urban revitalization and urban regeneration. What kinds of interventions do the concepts of regeneration and revitalization eventually refer to? According to Robert Beauregard and Briavel Holcomb, urban revitalization means putting 'new life' into cities and upgrading areas for 'higher' social and economic uses. ${ }^{7}$ Sean Zielenbach (2000) has identified two distinct approaches to revitalization: individual-based approaches focus on people and improvement of their living conditions (such as preventing unemployment), while place-based approaches stress local economic development and raising real estate values (such as actions that produce gentrification). ${ }^{8}$ The concepts of urban revitalization and urban regeneration are often used interchangeably. However, some authors, such as Robert Cowan, have distinguished the concepts by explaining urban regeneration to refer mainly to physical change and improvements of the environment, while revitalization is considered to refer to social improvements and other ways (such as cultural) of bringing a place to life. ${ }^{9}$

Culture may, however, have a crucial role in the physical transformation and development processes of urban space. Therefore, some scholars, like Graeme Evans, have examined the role of culture in urban regeneration in more detail. He has recognized three modes of incorporating cultural activity into the regeneration processes. He calls them: a) culture-led regeneration (cultural activity as a catalyst and engine of regeneration); b) cultural regeneration (cultural activity integrated into an area strategy alongside other activities in the environmental, social, and economic spheres); and c) culture and regeneration (cultural activity is not fully integrated into the strategic development of the area). ${ }^{10}$ On the one hand, decisionmakers and urban planners seem to believe that physical transformation of urban space is necessary to bring about urban development and stimulating economic growth. ${ }^{11}$ On the other hand, during the past couple of decades, culture-driven regeneration has occupied a pivotal position in contemporary urban policies. ${ }^{12}$ The combined aims of physical transformation of urban space and various cultural interventions into it form a common strategy in today's urban planning.

A commonly used and concrete means for cultural regeneration in contemporary cities is architecture. The past couple of decades have witnessed a variety of large-scale urban projects through which cities have sought to tackle their declining industries and economic regression by investing in major cultural institutions, such as cultural centers, art museums, and opera houses, and by constructing for these institutions unique buildings meant to function as global landmarks. ${ }^{13}$ Well-known examples of this kind of 'wow-architecture' range from the Sydney Opera House (1973) to the Bilbao Guggenheim Museum (1997), and from the Centre Georges Pompidou in Paris (1977) to the National Centre for the Performing Arts in Beijing (2007). The logic of 'wow-architecture' is entangled in its expected economic impact. World-famous architects have been invited to design outstanding and spectacular buildings in order to attract visitors and cultural actors, raise media attention, transform the city image, draw new investments to the city, etc. This kind of cultural regeneration strategy is extremely risky,

\footnotetext{
7 Robert Beauregard and Briavel Holcomb, Revitalizing Cities (Washington, DC: Association of American Geographers, 1981).

${ }^{8}$ Sean Zielenbach, The Art of Revitalization. Improving Condition of Distressed Inner-City Neighborhoods (London: Garland Publishing, 2000).

${ }^{9}$ Robert Cowan, The Dictionary of Urbanism (Tisbury: Streetwise Press, 2005).

${ }^{10}$ Graeme L. Evans, "Measure for Measure: Evaluating the Evidence of Culture's Contribution to Regeneration," Urban Studies 42, no. 5-6 (2005): 1-25.

${ }^{11}$ See for example, Teodoro Luque-Martinez, Salvador Del Barrio-García, José Ángel Ibáñes-Zapata, and Migual Ángel Rodriguez-Molina, "Modeling a City’s Image: The Case of Granada," Cities 24, no. 5 (2007): 335-352.

12 Jana Temelová, "Urban Revitalization in Central and Inner Parts of (Post-socialist) Cities: Conditions and Consequences," in Regenerating Urban Core, ed. Tuomas Ilmavirta (Espoo: Helsinki University of Technology, 2009), 15.

${ }^{13}$ Kai Horstmannshoff, The Loop. Chicago Architecture and the Social Imaginary (Bielefeld: Transcript, 2018).
} 
though, because of the massive scale, expense, and often limited substantial focus of these buildings. The 'wow-architecture' and cultural infrastructure-based projects are also relatively inflexible strategies of cultural regeneration and image-making. ${ }^{14}$ The concrete results of this kind of 'hard branding' of a city - based on the reputation and signature of global architectsand its impact on urban regeneration may be difficult to prove. ${ }^{15}$ The formula of constructing new spectacular cultural buildings to regenerate the city and its surrounding region and to transform the city's urban image may have been successful in some cities, but has failed at other sites and in different contexts. In the regeneration processes and attempts to transform the city image, much emphasis has commonly been placed on physical actions, while intangible projects have received less attention. ${ }^{16}$

The role of architecture in urban regeneration has often been discussed in relation to 'wow-architecture' and building new cultural infrastructure for major cultural institutions. However, one commonly used means of urban regeneration today is the use of temporary architectural intervention into city spaces, that is setting up non-permanent structures, constructions, or buildings for cultural and leisure use. In addition to urban planners and authorities, many civil associations also seek to revitalize urban spaces through event-oriented temporary architectural projects. ${ }^{17}$ Sometimes the forms of this kind of 'pop-up architecture' can be placed in the category of urban art, community art, or 'new genre public art', a term coined by Susanne Lacy ${ }^{18}$, because of their artistic and communal emphases and practices involving direct social engagement. Moreover, the communal and social emphasis of recent temporary architectural projects relates them to the tradition of activist architectural practices that Nishat Awan, Tatjana Schneider, and Jeremy Till have termed 'spatial agency'. ${ }^{19}$ These temporary event-oriented and artistic architectural projects are also closely linked to current urban culture and its aims to strengthen local communality and citizens' participation in selfmade bottom-up projects. Indeed, temporary architecture has become a timely urban trend that 'can hold a subversive and anti-system potential while, paradoxically, paraphrasing the material and spatial implications of finance capitalism in today's economy', as Marina Otero Verzier notes. ${ }^{20}$

\section{The European Capital of Culture Initiative as an Instrument for Urban Regeneration}

Major urban regeneration projects are long-term processes that are commonly included in the cities' development strategies aiming for long-term impacts and sustainability in economic, cultural, social, and environmental terms. Thus, urban regeneration projects involve diverse stakeholders in planning, decision-making, and implementation processes. Urban regeneration

\footnotetext{
${ }^{14}$ Ronan Paddison, “City Marketing, Image Reconstruction and Urban Regeneration," Urban Studies 30, no. 2 (1993): 339-350.

${ }^{15}$ Graeme L. Evans, "Hard-Branding the Cultural City: From Prado to Prada," International Journal of Urban and Regional Research 27, no. 2 (2003): 417-440; Evans, "Measure for Measure," 1-25.

${ }^{16}$ Teodoro Luque-Martinez et al., "Modeling a City's Image: the Case of Granada."

${ }^{17}$ Kelly Chan, "Pop-up Populism: How the Temporary Architecture Craze is Changing Our Relationship to the Built Environment," Artinfo, May 8, 2012.

${ }^{18}$ Susanne Lacy, "Introduction," in Mapping the Terrain. New Genre Public Art, ed. Suzanne Lacy (Seattle: Bay Press, 1995), 19-47.

${ }^{19}$ Nishat Awan, Tatjana Schneider, and Jeremy Till, Spatial Agency. Other Ways of Doing Architecture (London: Routledge, 2011).

${ }^{20}$ Marina Otero Verzier, "100 Urban Trends: Temporary Architecture," in 100 Urban Trends: A Glossary of Ideas from the BMW Guggenheim Lab, 13 August 2013, accessed October 5, 2017, https://www.guggenheim.org/blogs/lablog/100-urban-trends-temporary-architecture.
} 
is an important political instrument through which local and regional decision-makers and authorities seek to govern a variety of economic and social issues in the cities.

During its history, the ECOC initiative has evolved from a short-term high-cultural festival to a year-long urban event that enables manifold economic and social developments and regeneration of the city space. The ethos of a high-cultural festival changed particularly after Glasgow, Scotland, was selected as the ECOC for the year 1990. Since then various ECOCs have followed Glasgow's example and used the designation as a tool for reviving declined former industrial areas by investing in different branches of culture and promoting local cultural and creative industries. ${ }^{21}$ In addition, Glasgow's ECOC year has been described as a turning point in the alteration of the designation towards a city-marketing event. ${ }^{22}$ Over the years the ECOC designation has become a sought-after brand that cities use for image-making, place promotion, and city marketing. Greg Richards and Robert Palmer note how in the 2010s the ECOC initiative has been particularly characterized by investments in infrastructure. ${ }^{23}$ Following these views, Monica Sassatelli has described the current state of the initiative as a phase of 'capitalization', that is to say, cities compete to become recognized as capitals (in accordance with the name of the ECOC title), but capitalization also evokes economic capital as both a means and an outcome of economic processes. The ECOCs invest their assets in hope of greater economic as well as cultural returns. ${ }^{24}$

The ECOC designation has notably influenced urban development and transformation of the city space in several ECOCs in the Central and Eastern European countries that joined the EU in its Eastern enlargement in 2004 and 2007. The designation has previously had a similar kind of influence on cities in the so-called old EU member states. However, the transformation plans in the Central and Eastern European ECOCs have often been more comprehensive. The ECOC designation includes strong symbolic meanings and references to the idea of Europeanness - and thus the designation has been used in the 'new' EU member states as a tool for branding the city as European, indicating the city's belonging to a European cultural sphere, and, more broadly, in remapping or rethinking the cultural and political geography of Europe. ${ }^{25}$

In practice, the aims to regenerate urban space, invest in assets and (cultural) infrastructure, and boost economic growth through culture and cultural industries merge in the plans and policies of the ECOCs. Various ECOCs have used the initiative as a tool for reviving the city and developing its urban space, for example by upgrading cultural institutions and their facilities; modifying and modernizing squares and parks; revitalizing less-used or declined districts by preparing and cleaning their environment and installing public art in them; constructing new buildings for cultural use; renewing streets, roads and the transportation system; and renovating old estates and heritage sites. Particularly, the empty industrial estates of declined old industries close to the inner city have been transformed for use by cultural

\footnotetext{
${ }^{21}$ Robert Palmer, European Cities and Capitals of Culture. Part I (Brussels: European Commission \& Palmer/Rae Associates, 2004), 103 ; Kathrin Oerters and Jürgen Mittag, "European Capitals of Culture as Incentives for Local Transformation and Creative Economies: Tendencies - Examples - Assessments," in Whose Culture(s)? Proceedings of the Second Annual Conference of the University Network of European Capitals of Culture held in Liverpool 16-17 Oct 2008, ed. Wim Coudenys (Pécs: The University Network of European Capitals of Culture, 2008), 88-92.

22 Oerters and Mittag, "European Capitals of Culture as Incentives," 70.

${ }^{23}$ Greg Richards and Robert Palmer, Eventful Cities: Cultural Management and Urban Revitalisation (London: Routledge, 2010).

${ }^{24}$ Monica Sassatelli, "Europe's Several Capitals of Culture: From Celebration to Regeneration, to Polycentric Capitalization," in The Cultural Politics of Europe. European Capitals of Culture and European Union Since the 1980s, ed. Kiran K. Patel (London: Routledge, 2013), 64-66.

${ }^{25}$ Tuuli Lähdesmäki, "European Capital of Culture Designation as an Initiator of Urban Transformation in the Post-Socialist Countries," European Planning Studies 22, no. 3 (2014): 481-497; Tuuli, Lähdesmäki, Identity Politics in the European Capital of Culture Initiative (Joensuu: University of Eastern Finland, 2014).
} 
industries and as places of cultural and leisure time consumption. In spite of detailed plans, many of the large-scale construction and renovation projects in the ECOCs have not been either implemented or finished as planned due to increased expenses, financing problems, and a lack of investors.

The ECOC designation lasts only one year. Limited budgets and the short length of the designation have led many of the ECOCs to implement and host various small-scale architectural projects that influence an urban space only temporarily. Many of these projects aim to achieve the 'wow-effect' of spectacular architecture, but on a smaller scale and with much smaller expenses. On the one hand, the temporality and the small scale pose challenges for planning and implementation of architectural projects. On the other hand, they create possibilities for a new kind of experimentality and innovativeness regarding the material, form, location, function, and use of these constructions. In general, the development and regeneration practices in the ECOCs seek to modernize urban spaces by transforming them according to current notions of a 'good' and 'comfortable' environment and contemporary ideals of 'livable' cities.

To maximize the attention value of the ECOC designation, several cities have sought to produce new and exceptional spatial attractions in the city centers-particularly during the tourist season - in order to attract visitors, increase the local citizens' interest in their home city and its urban space, raise media attention, and have a positive influence on the city's image. These new spatial attractions have often been set up only for a couple of months and in unexpected and surprising locations in the city center. Thus, these projects can be described as architectural interventions, following the 'pop-up' ideology currently common in Western urban culture. Like pop-up restaurants, shops, and galleries in already existing buildings, popup architectural projects have sought to activate local citizens to experience and use urban space in a new way, bring people into less-used or unused urban spaces, and enable different people and groups to encounter each other within them. ${ }^{26}$

\section{Temporary Architectural Projects in Tallinn, Turku, Maribor, and Marseille}

The cultural programs in the recently designated ECOCs include several temporary architectural projects of which I have chosen four for closer examination. These cases were selected on the basis of their different regeneration objectives and concrete tactics for influencing an urban space and its uses and users. However, these cases have much in common: in all of them, the architectural interventions brought to the urban spaces, for a limited time (from a couple of months to a year), some exceptional structures that changed the meanings of the urban spaces, transformed their former uses, created a visual dialog between the elements of the spaces, and produced the possibility to experience the urban spaces in a new way. What follows is a description of the differences and similarities in the selected temporary architectural projects and a discussion on how the projects sought to function as a means of urban regeneration in their host cities. The tactics of temporality and the goals for urban regeneration in the cases are summarized in Table 1 at the end of the section.

Tallinn, the capital of Estonia, was designated as the ECOC for 2011. The biggest cultural project in the city, created particularly for the ECOC year, was the Straw Theatre-a temporary theatre building in which the Estonian Theatre NO99 and other artists performed their plays, concerts, and works of art from May to September 2011. The building, designed by Salto Architects (Maarja Kask, Karli Luik, Ralf Lõoke, and Pelle-Sten Viiburg), consisted

${ }^{26}$ Tuuli Lähdesmäki, "Pop-up Architecture as Urban Regeneration," in Dialectics of Space and Place across Virtual and Corporeal Topographies, ed. by June Jordaan, Carl Haddrell, and Christine Alegria (Oxford: InterDisciplinary Press, 2016), 263-274. 
of uncovered straw bales that were spray-painted black and supported by a wooden frame. The theatre was located next to the Old Town on the Skoone Bastion - a neglected and decayed site that once had a wooden navy theatre and a park during the Soviet occupation of the country. After the Soviet troops left the country and the old theatre burned down, the bastion remained a closed and abandoned site that was not taken into any real-estate or recreational use, although during the past two decades various urban development plans were drafted for the site.

The temporary Straw Theatre offered a possibility to reactivate the unused location and test its potential for cultural and leisure use. The surroundings of the Straw Theatre were transformed into an open 'living room' for the local citizens and visitors. The area in front of the theatre was covered by a lawn and a wooden terrace. It included a sandpit, a hopscotch court, a grill, a snack bar, and a space where for the visitors could read cultural magazines. The venue of the theatre was described as follows in the official program book of the ECOC year of Tallinn:

Everybody is welcome to do their morning workout there, play with their children on the playground, read intellectually enthralling magazines, eat healthy food or just listen to the birds singing and gaze at the sea. ${ }^{27}$

The Straw Theatre succeeded in drawing local citizens from all age groups, including families, to spend time in the recreated area. The performances in the theatre attracted a lot of visitors: both the media and the audience thanked the program for its high quality, internationalism, and topicality. The project succeeded in turning the decayed site into an urban experiment in which a 'non-place' close to the city center could be experienced in a new way and given new meanings. The spectacular look and the ecological and experimental — but at the same time profoundly traditional - material of the building raised much interest in the media and among the local citizens and tourists. The wow-effect of the architecture brought a lot of people to the site just to marvel at the building.

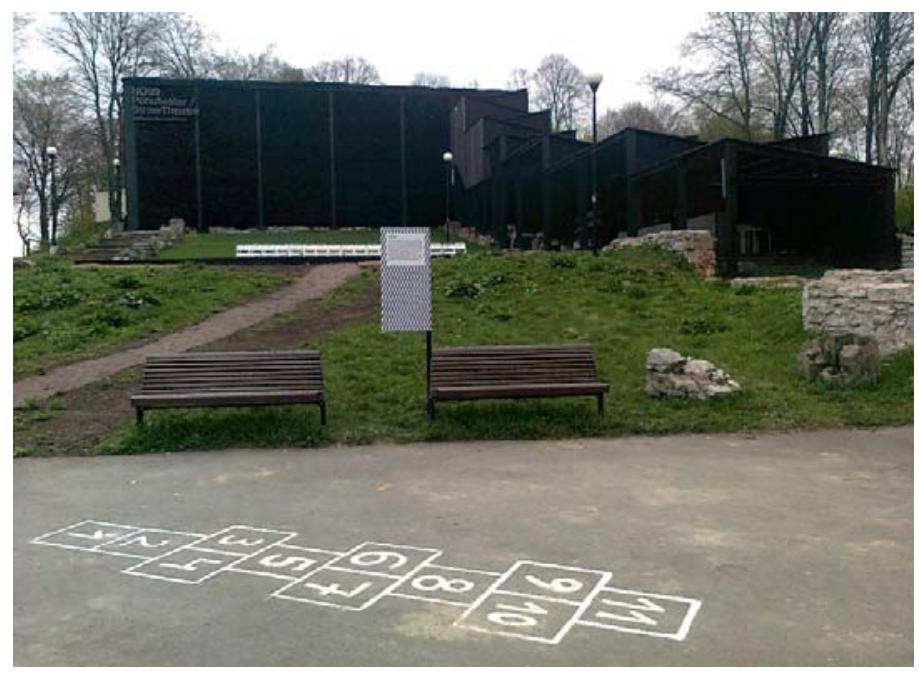

Figure 2.2. Straw Theatre, designed by Salto Architects, in Tallinn, Estonia, in May 2011. Photo: Tuuli Lähdesmäki.

\footnotetext{
27 Andri Maimets and Maris Hellrand, eds., Tallinn - European Capital of Culture. Stories of the Seashore. Programme (Tallinn: Tallinn 2011 Foundation, 2010), 96.
} 


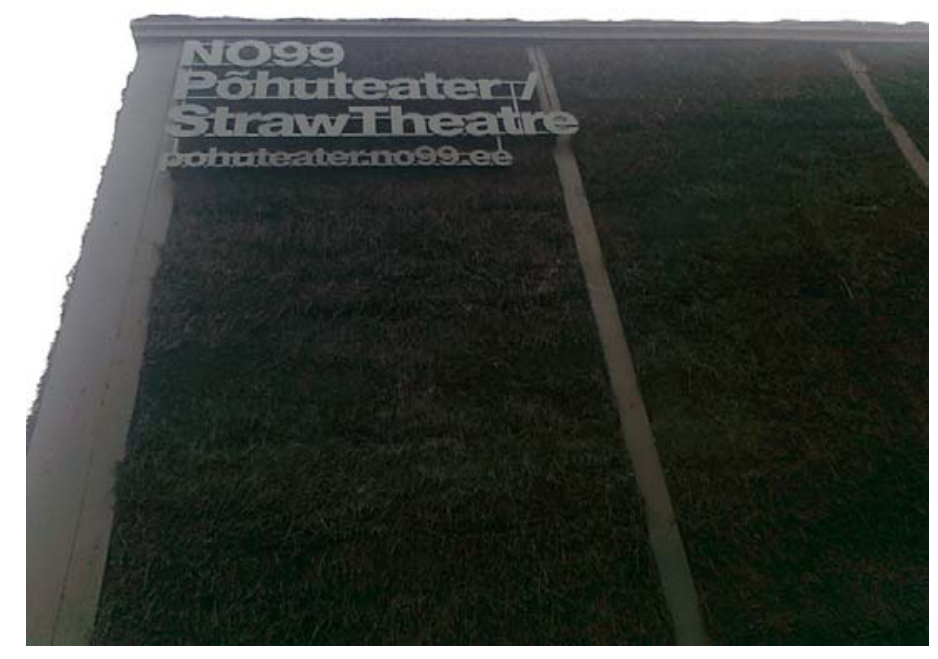

Figure 2.3. Straw Theatre (detail), designed by Salto Architects, in Tallinn, Estonia, in May 2011. Photo: Tuuli Lähdesmäki.

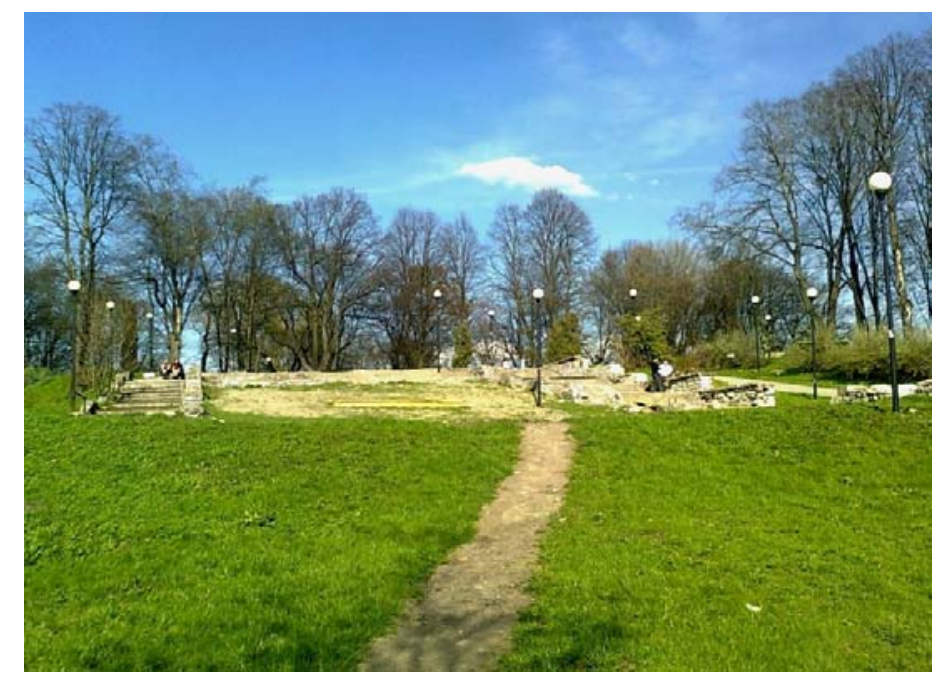

Figure 2.4. Site of the Straw Theatre, in Tallinn, Estonia, in May 2012. Photo: Tuuli Lähdesmäki.

After five months the theatre was taken down and the site was returned to its previous state. The building did not leave any permanent marks on the environment; it respected the historical layers of the site, for example, by utilizing the remaining stone bases and staircases of the earlier navy theatre. Skateboarders and local youth continued to meet at the site.

Turku, a city in southwest Finland, was designated as the ECOC for 2011 together with Tallinn. The major architectural project in Turku's cultural program was the Sauna Lab. In the project, four Finnish artists (Jan-Erik Anderson, Heidi Lunabba, Harri Markkula, and HansChristian Berg) were invited to design site-specific artistic saunas, which were located in different sites in the city center and nearby districts for the summer months. Saunas are a profoundly traditional and living part of Finnish culture. However, the long tradition of public saunas has been diminishing during the past decades as most people bath in their own private saunas. The aim of the Sauna Lab was to bring together traditional Finnish culture and an 
innovative contemporary design, blur the ideas of an intimate space and a public space, revitalize the tradition of urban public saunas, and bring new communal elements to the urban space. The saunas were in public use and could be reserved for groups from June to August.

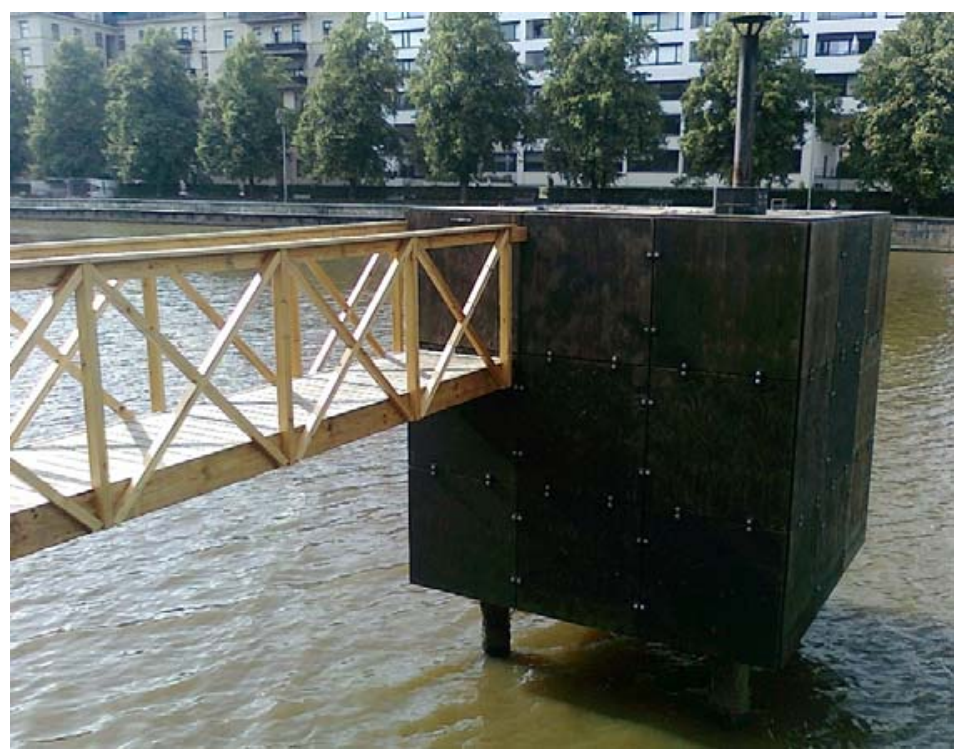

Figure 2.5. Temporary sauna Hot Cube, designed by Harri Markkula, in Turku, Finland, in August 2011. Photo: Tuuli Lähdesmäki.

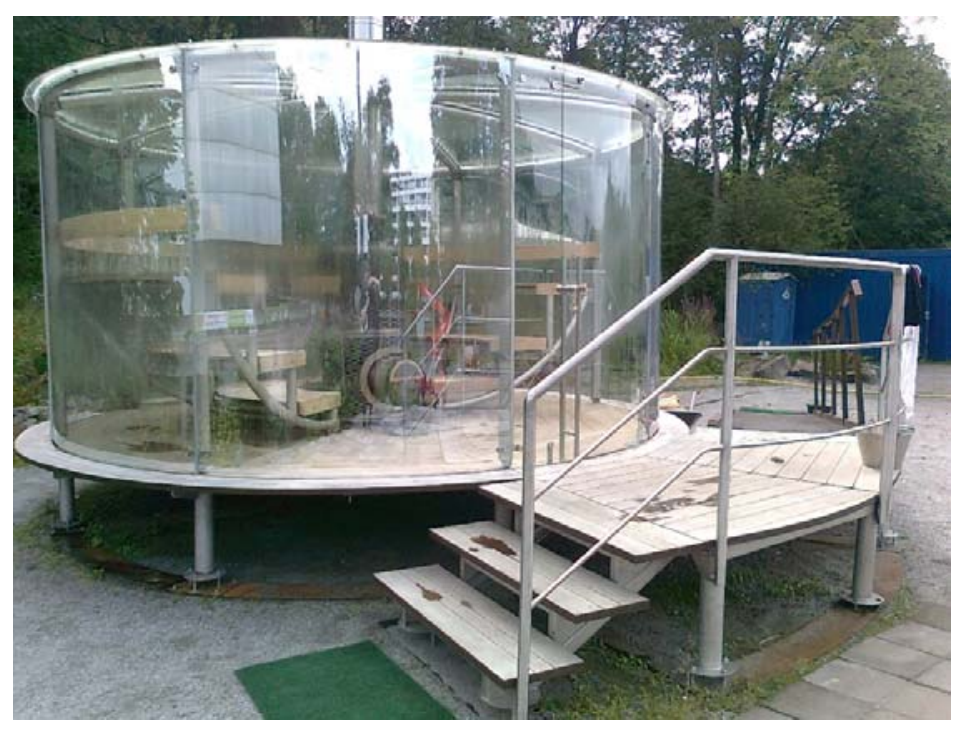

Figure 2.6. Temporary sauna Solaris, designed by Hans-Christian Berg and Mika Ihanus, in Turku, Finland, in August 2011. Photo: Tuuli Lähdesmäki.

All the temporary saunas in Turku relied on unique forms and artistic elements in their design. Anderson's Sounding Dome Sauna was made of fiberglass and was from the outside reminiscent of a giant yellow garlic bulb. Inside the sauna, the bathers could listen to the work of sound artist Shawn Decker. The sauna was located in a local open-air swimming arena. Lunabba's Sauna Obscura floated on a raft in the sea near a public beach. The sauna was based on the idea of a camera obscura: the surrounding environment of the Turku Archipelago was 
projected upside down on the walls of the sauna and the skins of the bathers blurring the border between the inside and the outside, turning the sauna into a kind of live movie theatre. Markkula's Hot Cube was located in the city center above the Aura River, which flows through the city. The sauna was made using tarred wooden panels that formed a windowless cube. The river could be seen through lattices in the sauna floor. Breg's Solaris, designed in cooperation with industrial designer Mika Ihanus, was a transparent round glass building located on a small hill next to one of the city's art museums, a busy road, and a bridge crossing the Aura River.

The Sauna Lab brought unexpected functions to the urban space by offering the possibility of bathing and relaxing in the urban space, and meeting other citizens and cultural tourists within an intimate space. The artistic design of the saunas sparked much interest in the media and among citizens and tourists. According to the bathers, bathing in an artistically unique sauna in an unexpected place in the city was experienced as extraordinary and unforgettable. In September 2011 the saunas were removed: some of them were offered for sale and some of their prototypes were introduced for further production. All the saunas have reappeared in some other venue or have visited other cities as a part of some event or cultural festival.

Whether influenced by the Sauna Lab or not, during the past few years the tradition of public saunas has undergone a rapid recovery in Finland, as two public 'design' saunas have been set up in the center of the capital city Helsinki. Their popularity among the local people and tourists has recently inspired launches of similar plans in other major Finnish cities, as well.

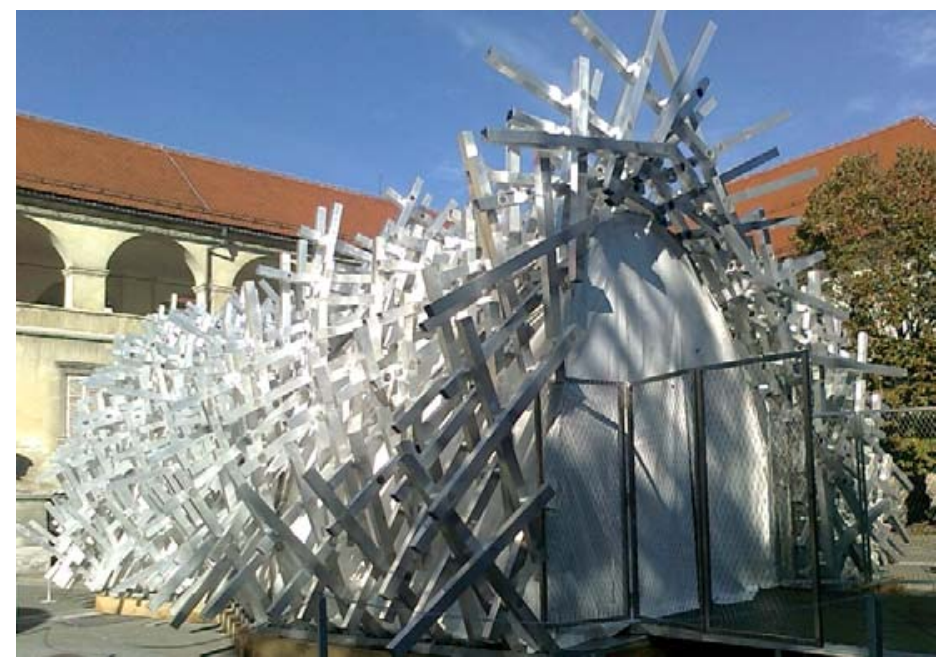

Figure 2.7. White Noise, designed by the SOMA collective, in Maribor, Slovenia, in October 2012. Photo: Tuuli Lähdesmäki. 


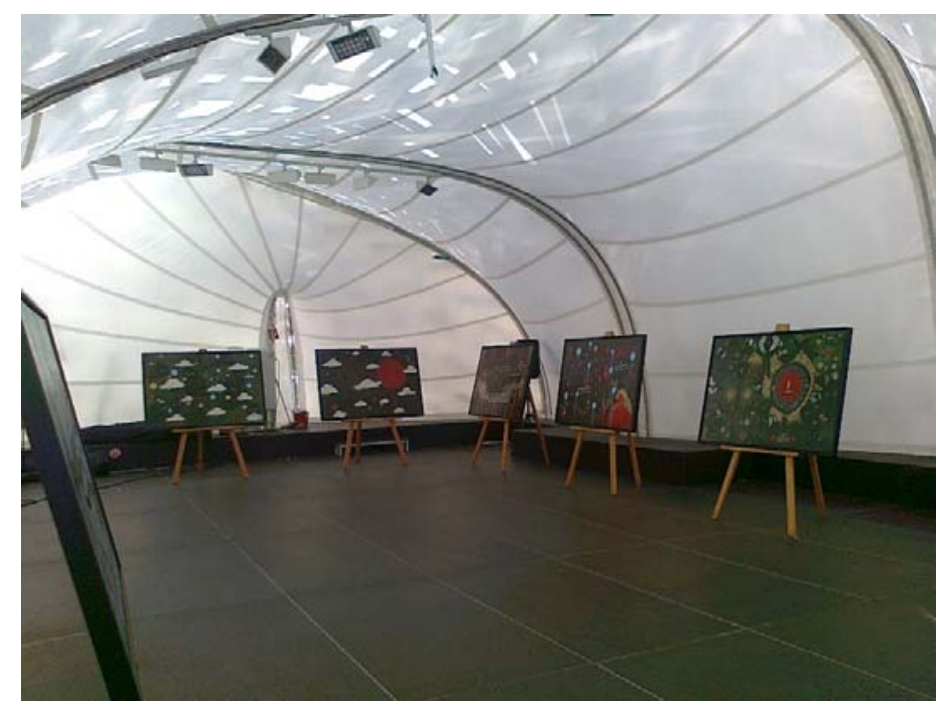

Figure 2.8. Exhibition 'Ten' by Nenad Cizl in White Noise, designed by the SOMA collective, in Maribor, Slovenia, in October 2012. Photo: Tuuli Lähdesmäki.

Maribor, a city in Northern Slovenia, was designated as one of the ECOCs for 2012. During the year one of the main squares in the city, the Trg Svobode, functioned as the location of a temporary exhibition space called White Noise. It was designed by Austrian architecture collective SOMA (Johan Tali, Alex Matl, and Karin Dobbler), which in 2011 won an open architectural competition held by the Salzburg Regional Government with the purpose of promoting contemporary architecture and architectural interventions into public space. The pavilion was constructed of 1500 aluminum bars, which were connected following a set of rules and variations to form an organic sculpture-like structure. The aluminum structure of the pavilion was lined with a tarp.

After the win, the SOMA architects toured various cities with the pavilion. Maribor bought it for six weeks as a part of the city's ECOC program. From September to October 2012 the pavilion hosted diverse small concerts, exhibitions, discussions, and screenings in the city. The look of the pavilion was extraordinary and eye-catching, forming a strong contrast with the historical buildings surrounding the square. It also brought new cultural uses to the square, which is used for fairs and as a market place and on which is located a large bronze monument of the National Liberation War.

The White Noise pavilion is an example of an international, temporary, and movable artistic and architectural project that can be situated for a limited period of time in an urban space to bring it to life in a new way and to activate cultural and communal participation by the citizens. Similar kinds of 'touring' projects have been utilized by several recent ECOCs as part of their cultural programs. ${ }^{28}$

Marseille, the French city on the shore of the Mediterranean Sea, was designated as one of the ECOCs for 2013. The city authorities commissioned vast development plans for the cultural year and implemented various costly regeneration projects in which public spaces in the city center were renovated and new impressive buildings were constructed. Especially the Museum of European and Mediterranean Civilisations (MuCEM) designed by architect Rudy

\footnotetext{
${ }^{28}$ For example, the Flying Grass Carpet, a project by Dutch HUNK-Design and ID-Eddy, which consists of a combination of several artificial grasses with different characteristics and colors woven together to resemble a huge Persian carpet, visited in 2010 three ECOCs: Pécs (Hungary), Essen (Germany), and Istanbul (Turkey). The Colourscape, a project by English Eye Music Trust comprising a huge walk-in network of interconnected chambers that bend the colors of light, visited Turku in August 2011.
} 
Ricciotti and the conference center Villa Méditerranée designed by architect Stefano Boeri can be regarded as 'wow-architecture'.

In addition to these permanent architectural projects, one of the core spots in Marseille during its ECOC year was a temporary information center and cultural venue M Pavilion designed by Philippe Malta. The pavilion was built over an extension of the city hall and it thereby utilized an already-existing architectural space. The extension of the city hall of Marseille was commissioned by the city government from architect Franck Hammoutène, who won the competition on the project in 1999. The extension was completed in 2006, following the recently much-discussed spatial ideas of underground architecture ${ }^{29}$ : new municipal offices, meeting rooms, exhibitions spaces, and a large foyer covering altogether 8300 square meters were located under the ground level next to the old 17 th century city hall. Above the extension, a new public space was created by covering and refurbishing the VilleneuveBargemon square and by letting the square follow the original form of the landscape, sloping towards the nearby Old Port.

The M Pavilion was constructed partly in front of the entrance to the extension of the city hall and partly above it by utilizing the its foyer, exhibition spaces, and large meeting room as part of the pavilion. The temporary construction of the pavilion covered 1200 square meters, forming a wave-like shape on the side of the square. The pavilion was built using a wooden framework supporting large sheets of polycarbonate, which let daylight into the building to create a transparent impression. The fundamental idea in its construction was sustainability: when dismantled, all of its components could be reused or recycled.

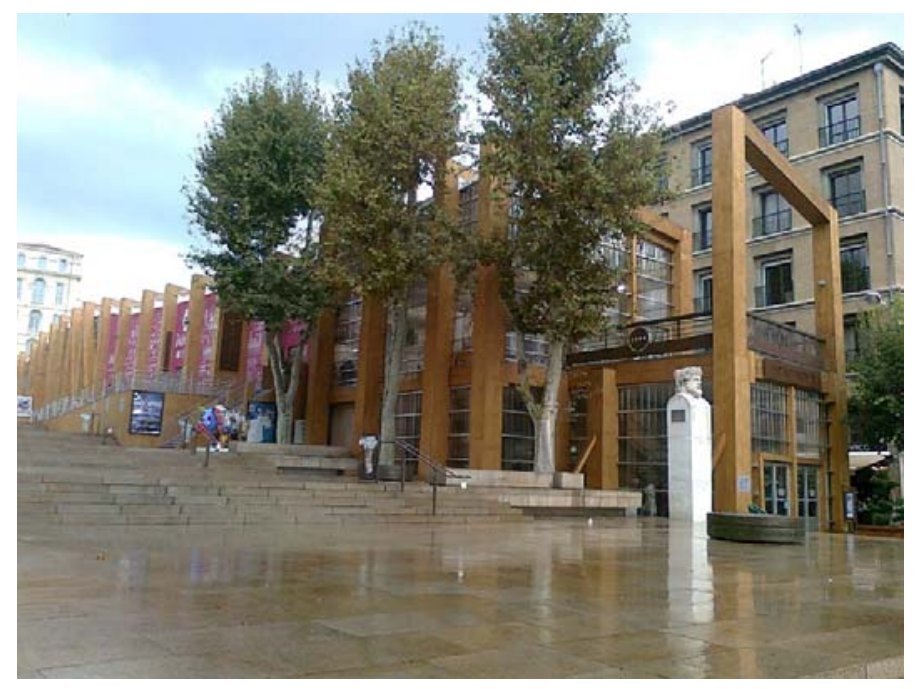

Figure 2.9. The M Pavilion, designed by Philippe Malta, in Marseille, France, in October 2013. Photo: Tuuli Lähdesmäki.

\footnotetext{
${ }^{29}$ Ernst von Meijenfeldt et al., Below Ground Level: Creating New Spaces for Contemporary Architecture (Basel: Birkhäuser, 2003).
} 


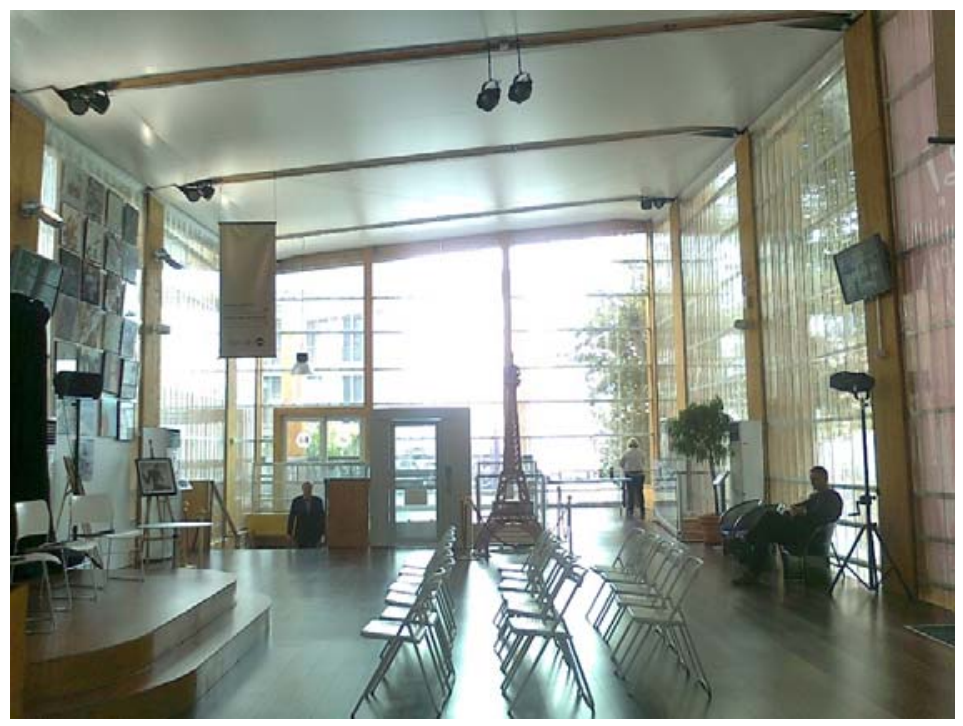

Figure 2.10. Lobby of the M Pavilion, designed by Philippe Malta, in Marseille, France, in October 2013. Photo: Tuuli Lähdesmäki.

The M Pavilion was opened in January 2013 and dismantled in February 2014. During that time, 1.2 million people visited it. ${ }^{30}$ Its main purpose was to function as a showcase venue for the cultural program of Marseille's ECOC year and communicate with the citizens and visitors about the city. The pavilion succeeded in serving as a meeting place in the city, spurring several citizens to wish at the end of the ECOC year for the legacy of the pavilion to be continued and a new building dedicated to culture to be set up in the city.

Table 1. Tactics of temporality in the architectural case projects and their goals for urban regeneration.

\begin{tabular}{|c|l|l|}
\hline Cases & \multicolumn{1}{|c|}{ Tactics of Temporality } & \multicolumn{1}{c|}{ Goals for Urban Regeneration } \\
\hline $\begin{array}{c}\text { The Straw } \\
\text { Theatre } \\
\text { (Tallinn) }\end{array}$ & $\begin{array}{l}\text { • ecological, traditional, non- } \\
\text { permanent construction material } \\
\bullet \text { utilization of previous structures } \\
\text { on the site as a part of the } \\
\text { building }\end{array}$ & $\begin{array}{l}\text { ・ to enliven a less-used and decayed } \\
\text { site near the city center with an } \\
\text { attractive design }\end{array}$ \\
$\begin{array}{c}\bullet \text { to create an 'urban living room' } \\
\text { for the citizens } \\
\bullet \text { to provide a new venue for cultural } \\
\text { performances }\end{array}$ \\
\hline $\begin{array}{c}\text { Sauna Lab } \\
\text { (Turku) }\end{array}$ & $\begin{array}{l}\text { projects of which some were sold } \\
\text { and some introduced for further } \\
\text { production }\end{array}$ & $\begin{array}{l}\text { - to create new surprising use for } \\
\text { urban spaces } \\
\bullet \text { to merge architecture and art } \\
\text { to bring new communal activities } \\
\text { to the city center }\end{array}$ \\
\hline
\end{tabular}

30 "MP13: le Pavillon M a accueilli 1,2 million de visiteurs," La Provence.com, 31 December 2013, accessed May 30, 2014, http://www.laprovence.com/actu/leco-en-direct/2688098/mp13-le-pavillon-m-a-accueilli-12-millionde-visiteurs.html. 


\begin{tabular}{|c|l|l|}
\hline $\begin{array}{c}\text { White Noise } \\
\text { (Maribor) }\end{array}$ & $\begin{array}{l}\bullet \text { a movable architectural project } \\
\text { that can be bought to a site for a } \\
\text { short duration }\end{array}$ & $\begin{array}{l}\bullet \text { to provide a new attractive venue } \\
\text { for cultural performances }\end{array}$ \\
\hline $\begin{array}{c}\text { The M Pavilion } \\
\text { (Marseille) }\end{array}$ & $\begin{array}{l}\text { with techniques that enabled } \\
\text { dismantling of the building and } \\
\text { recycling of its elements } \\
\text { utilization of current } \\
\text { architectural space on the site }\end{array}$ & $\begin{array}{l}\bullet \text { to create a new meeting place for } \\
\text { the citizens in the city center } \\
\text { to provide a new venue for cultural } \\
\text { performances }\end{array}$ \\
\hline
\end{tabular}

\section{Contextualizing Recent Temporary Architecture}

The current interest in regenerating urban spaces by setting up temporary buildings, such as the case projects of this study, reflects recent theoretical discussions on and conceptualizations of urban planning. The focus of these discussions is on the idea and ideal of increasing interaction and communication between citizens in these urban spaces, strengthening communality and urban identities in the city, rediscovering the city center and its activities, and fostering human-scale and pedestrian-friendly urban design as a basis for 'livable' cities.

Nigel Taylor has identified a paradigmatic change in urban planning theories and practices during the 1990s. According to him, at that time views in urban planning started to follow a new communicative paradigm. It meant a new emphasis on interaction and communication instead of 'pure' rational, scientific, and technical thinking as the bases for managing urban planning. ${ }^{31}$ The emphasis on interaction and communication easily incorporated cultural points of view into the aims and ideas of urban planning. Indeed, cultural planning has become one of the key points in urban planning discourses. These kinds of ideas and emphases in urban planning have also been described as characterizing the shift from modern to post-modern urban planning principles. ${ }^{32}$ The ideals of post-modern urban planning are considered to include, for example, fostering of urban identities and appreciation of history and traditions of places, participatory planning methods, and pursuit of human-scale and compact urban forms. ${ }^{33}$ Moreover, similar ideas characterize the planning principles conceptualized as New Urbanism. It stresses, for example, a rediscovery of the city center and its activities, pedestrian-friendly urban design, diversity and openness of the public space, urban esthetics, quality of design, and communality and interaction of citizens in order to increasingly enliven the urban environment. ${ }^{34}$

The recent ideas of urban planning intertwine with the economic and social motives described in the second section of this chapter. Besides cultural and creative economy, the current aims of urban planning reflect the ideas brought together in the concept of experience economy. Some scholars have described these ideas as 'economy of fascination' in order to emphasize how cities have been competitively themed to market their unique 'experience world'. ${ }^{35}$ During the past three decades, politicians, planners, and marketing experts have

\footnotetext{
${ }^{31}$ Nigel Taylor, Urban Planning Theory Since 1945 (London: Sage, 1998).

32 Sonia A. Hirt, "Towards Postmodern Urbanism? Evolution of Planning in Cleveland, Ohio," Journal of Planning Education and Research 25, no. 1 (2005), 29.

${ }^{33}$ Hirt, "Towards Postmodern Urbanism?"

${ }^{34}$ Tigran Haas, ed., New Urbanism \& Beyond. Designing Cities for the Future (New York: Rizzoli, 2008).

${ }^{35}$ For example, Heiko Schmid, Economy of Fascination. Dubai and Las Vegas as Themed Urban Landscapes (Berlin: Gebrüder Borntraeger, 2009).
} 
increasingly focused on developing experiences in order to foster consumption. ${ }^{36}$ As a consequence, cities have started to seek possibilities to offer people spectacular urban environments, designed for these moments of extraordinary experiences, to profit from their interest in gaining new experiences. ${ }^{37}$ Experience-focused urban planning has moved more and more from investing in 'hard' location factors, such as major buildings, towards 'soft' location factors, such as recreational activities and place-based installations. ${ }^{38}$ Estheticization of an urban space is at the same time a means and an outcome of experienced-focused urban planning. On the one hand, estheticization is a process that seeks to create novelty, surprise, and excitement, but on the other hand, it may only result in superficial changes. ${ }^{39}$ As AnneMarie d'Hauteserre states:

The aestheticisation of urban neighbourhoods represents a concern with the production of difference relative to the visibility of phenomena, mustering emotion and affect through iconic images and spectacle, creating a dreamscape for visual consumption, a spectacular experience. ${ }^{40}$

Many of the ECOCs have sought to boost tourism in the cities by offering visitors diverse recreational and cultural activities and spectacular urban places. Daniel Habit claims that the urban spaces in the ECOCs have even been turned into 'citytainment' ${ }^{41} \mathrm{He}$ even compares the implementation of the ECOC year of Sibiu in Romania in 2007 to the process described as disneyfication. ${ }^{42}$ David Harvey has used the concept of disneyfication to describe attempts to transform the urban environment into safe and clean spaces of entertainment, which promote the city and attract capital, tourists, and people who share similar values. ${ }^{43}$ The logic of Disneyland has globally influenced various initiatives and attempts to organize leisure activities and build environments for them. ${ }^{44}$

\section{Conclusions}

The explored cases from the four ECOCs indicate that temporary architectural projects can revitalize, regenerate, and produce new meanings for urban spaces, activate people to use public spaces in a new way, increase social interaction in the city, and raise positive public attention. Temporary architectural projects are easy, fast, cheap, and less risky modes of creating wow-effects within urban spaces - an outcome that urban planners often long forthan large-scale 'wow-architecture'. On the one hand, the cultural, social, and economic impacts of temporary projects may be short-term and limited in scale. On the other hand, temporality respects the existing structures and historical layers of the city without seeking to change the urban space permanently. Temporality enables implementation of innovative

\footnotetext{
${ }^{36}$ Doreen Jakob, "The Eventification of Place: Urban Development and Experience Consumption in Berlin and New York City," European Urban and Regional Studies 20, no. 4 (2013), 447-459.

${ }^{37}$ Anne-Marie d'Hauteserre, "Val d'Europe: A Pioneering Turn to 'Experience' Planning?" European Urban and Regional Studies 20, no. 4 (2013), 435-446.

${ }^{38}$ Peter Allingham, “Art, Media, and Sense-making in Responsive Urban Environments," Rask 40 (2014), 31-52.

${ }^{39}$ d'Hauteserre, "Val d'Europe: A Pioneering Turn to 'Experience' Planning?” 437.

40 Ibid.

${ }^{41}$ Daniel Habit, "Pheripheral ECOCs between Cultural Policy and Cultural Governance: The Case of Sibiu 2007," in The Cultural Politics of Europe. European Capitals of Culture and European Union Since the 1980s, ed. Kiran K. Patel (London: Routledge, 2013), 132.

${ }^{42}$ Id., 134.

${ }^{43}$ David Harvey, The Condition of Postmodernity (Oxford: Basil Blackwell, 1989).

${ }^{44}$ John Hannigan, Fantasy City. Pleasure and Profit in the Postmodern Metropolis (London: Routledge, 1998).
} 
architectural and communal experiments, playing with the experiential and affective dimensions of the urban space, and fast and flexible reaction to changing social dynamics in the city.

Contemporary views in urban regeneration particularly emphasize the role of local communities in planning and implementing regeneration projects. As a consequence, social and community regeneration has been recognized as an integral part of urban regeneration. ${ }^{45}$ Today, the success of urban regeneration projects is not only measured by physical transformation of the city space or its economic impact, but also by its outcomes in creating vibrant communities, interaction between citizens, a feeling of comfort in the urban space, active participation in cultural and social issues, and interest in the urban environment. Attempts to enliven city centers and make cities more 'livable' often originate from top-down decision-making and urban planning practices - of which the ECOC initiative functions as an example. Scholars have criticized these practices for forgetting to involve local people and ordinary citizens in the urban planning and regeneration processes. ${ }^{46}$

Temporary small-scale experimental architectural projects could offer possibilities for more effective inclusion of local people in communal and cultural development and regeneration of the urban environment. Pop-up ideology enables the citizens to plan and implement grass-roots and bottom-up initiatives and create temporary venues for communal and cultural activities. The future of the ECOC initiative will show whether the possibilities of temporary architecture will be better utilized in urban and community regeneration and whether the bottom-up initiatives planned and implemented by the citizens themselves will include temporary space-making and architectural projects that enliven the city.

\footnotetext{
${ }^{45}$ Rachel Granger, "Social and Community Issues," in Urban Regeneration, eds. Peter Roberts, Hugh Sykes, and Rachel Granger (London: Sage, 1999), 107-110.

${ }^{46}$ Tim Hall, "Public Art, Civic Identity and the New Birmingham," in Remaking Birmingham: The Visual Culture of Urban Regeneration, ed. Liam Kennedy (London: Routledge, 2004), 71; Beatriz García, "Cultural Policy and Urban Regeneration in Western European Cities: Lesson from Experience, Prospects for the Future," Local Economy 19, no. 4 (2004): 312-326; Evans, "Measure for Measure," 1-25.
} 


\section{Bibliography}

Allingham, Peter. "Art, Media, and Sense-making in Responsive Urban Environments." Rask 40 (2014): 31-52.

Awan, Nishat, Tatjana Schneider, and Jeremy Till. Spatial Agency. Other Ways of Doing Architecture. London and New York: Routledge, 2011.

Beauregard, Robert and Briavel Holcomb. Revitalizing Cities. Washington, DC: Association of American Geographers, 1981.

Bonet, Lluís and Emmanuel Négrier. "The Ends(s) of National Cultures? Cultural Policy in the Face of Diversity.” International Journal of Cultural Policy 17, no. 5 (2011): 574-589.

Chan, Kelly. "Pop-up Populism: How the Temporary Architecture Craze is Changing Our Relationship to the Built Environment." Artinfo, May 8, 2012. http://www.artinfo.com.

Cowan, Robert. The Dictionary of Urbanism. Tisbury: Streetwise Press, 2005.

Evans, Graeme L. "Hard-Branding the Cultural City: From Prado to Prada." International Journal of Urban and Regional Research 27, no. 2 (2003): 417-440.

Evans, Graeme L. "Measure for Measure: Evaluating the Evidence of Culture's Contribution to Regeneration.” Urban Studies 42, no. 5-6 (2005): 1-25.

García, Beatriz. "Cultural Policy and Urban Regeneration in Western European Cities: Lesson from Experience, Prospects for the Future.” Local Economy 19, no. 4 (2004): 312-326.

Granger, Rachel. "Social and Community Issues," In Urban Renegeration, edited by Peter Roberts, Hugh Sykes, and Rachel Granger, 99-112. London: Sage, 1999.

Haas, Tigran, ed. New Urbanism \& Beyond. Designing Cities for the Future. New York: Rizzoli, 2008.

Habit, Daniel. "Pheripheral ECOCs between Cultural Policy and Cultural Governance: The Case of Sibiu 2007." In The Cultural Politics of Europe. European Capitals of Culture and European Union Since the 1980s, edited by Kiran K. Patel, 127-140. London: Routledge, 2013.

Hall, Tim. "Public Art, Civic Identity and the New Birmingham." In Remaking Birmingham: The Visual Culture of Urban Regeneration, edited by Liam Kennedy, 63-71. London: Routledge, 2004.

Hannigan, John. Fantasy City. Pleasure and Profit in the Postmodern Metropolis. London: Routledge, 1998.

Harvey, David. The Condition of Postmodernity. Oxford: Basil Blackwell, 1989.

d'Hauteserre, Anne-Marie. "Val d'Europe: A Pioneering Turn to 'Experience' Planning?" European Urban and Regional Studies 20, no. 4 (2013): 435-446. 
Hirt, Sonia A. "Towards Postmodern Urbanism? Evolution of Planning in Cleveland, Ohio." Journal of Planning Education and Research 25, no. 1 (2005): 27-42.

Horstmannshoff, Kai. The Loop. Chicago Architecture and the Social Imaginary. Bielefeld: Transcript, 2018.

Jakob, Doreen. "The Eventification of Place: Urban Development and Experience Consumption in Berlin and New York City." European Urban and Regional Studies 20, no. 4 (2013), 447-459.

Lacy, Susanne. "Introduction." In Mapping the Terrain. New Genre Public Art, edited by Suzanne Lacy, 19-47. Seattle: Bay Press, 1995.

Lähdesmäki, Tuuli. "European Capital of Culture Designation as an Initiator of Urban Transformation in the Post-Socialist Countries." European Planning Studies 22, no. 3 (2014): 481-497.

Lähdesmäki, Tuuli. Identity Politics in the European Capital of Culture Initiative. Joensuu: University of Eastern Finland, 2014.

Lähdesmäki, Tuuli. "Pop-up Architecture as Urban Regeneration." In Dialectics of Space and Place across Virtual and Corporeal Topographies, edited by June Jordaan, Carl Haddrell, and Christine Alegria, 263-274. Oxford: Inter-Disciplinary Press, 2016.

La Provence.com. "MP13: le Pavillon M a accueilli 1,2 million de visiteurs." December 31, 2013. Accessed May 30, $2014 . \quad \mathrm{http}: / / \mathrm{www}$. laprovence.com/actu/leco-endirect/2688098/mp13-le-pavillon-m-a-accueilli-12-million-de-visiteurs.html.

Luque-Martinez, Teodoro, Salvador Del Barrio-García, José Ángel Ibáñes-Zapata, and Migual Ángel Rodriguez-Molina. "Modeling a City's Image: the Case of Granada." Cities 24, no. 5 (2007): 335-352.

MacCannell, Dean. The Tourist. A New Theory of the Leisure Class. New York: Schocken Books, 1989.

Maimets, Andri and Maris Hellrand, eds. Tallinn - European Capital of Culture. Stories of the Seashore. Programme. Tallinn: Tallinn 2011 Foundation, 2010.

von Meijenfeldt, Ernst, et al. Below Ground Level: Creating New Spaces for Contemporary Architecture. Basel: Birkhäuser, 2003.

Näss, Hans Erik. "The Ambiguities of Intercultural Dialogue: Critical Perspectives on the European Union's New Agenda for Culture." Journal of Intercultural Communication 23 (2010). Accessed October 5, 2017. https://www.immi.se/intercultural/nr23/nass.htm.

Oerters, Kathrin and Jürgen Mittag. "European Capitals of Culture as Incentives for Local Transformation and Creative Economies: Tendencies - Examples - Assessments." In Whose Culture(s)? Proceedings of the Second Annual Conference of the University Network of 
European Capitals of Culture held in Liverpool 16-17 Oct 2008, edited by Wim Coudenys, 70-97. Pécs: The University Network of European Capitals of Culture, 2008.

Otero Verzier, Marina. "100 Urban Trends: Temporary Architecture.” In 100 Urban Trends: A Glossary of Ideas from the BMW Guggenheim Lab. August 13, 2013. Accessed October 5, 2017. https://www.guggenheim.org/blogs/lablog/100-urban-trends-temporary-architecture.

Paddison, Ronan. "City Marketing, Image Reconstruction and Urban Regeneration." Urban Studies 30, no. 2 (1993): 339-350.

Palmer, Robert. European Cities and Capitals of Culture. Part I. Brussels: European Commission \& Palmer/Rae Associates, 2004.

Richards, Greg and Robert Palmer. Eventful Cities: Cultural Management and Urban Revitalisation. London: Routledge, 2010.

Sassatelli, Monica. "Europe's Several Capitals of Culture: From Celebration to Regeneration, to Polycentric Capitalization." In The Cultural Politics of Europe. European Capitals of Culture and European Union Since the 1980s, edited by Kiran K. Patel, 55-71. London: Routledge, 2013.

Schmid, Heiko. Economy of Fascination. Dubai and Las Vegas as Themed Urban Landscapes. Berlin: Gebrüder Borntraeger, 2009.

Taipale, Kaarin. Cities for Sale. How Economic Globalization Transforms the Local Public Sphere. Centre for Urban and Regional Studies Publications. Studies in Architecture A 36. Espoo: Helsinki University of Technology, 2009.

Taylor, Nigel. Urban Planning Theory Since 1945. London: Sage, 1998.

Temelová, Jana. "Urban Revitalization in Central and Inner Parts of (Post-socialist) Cities: Conditions and Consequences." In Regenerating Urban Core, edited by Tuomas Ilmavirta. Publications in the Center for Urban and Regional Studies C72, 12-25. Espoo: Helsinki University of Technology, 2009.

Vitruvius. The Ten Books on Architecture. Translated by Morris Hicky Morgan. Cambridge: Harvard University Press, 1914.

Zielenbach, Sean. The Art of Revitalization. Improving Condition of Distressed Inner-City Neighborhoods. London: Garland Publishing, 2000. 